\title{
Let the fog be lifted: screening for hepatitis B virus before biological therapy
}

\author{
Kevin L Winthrop, ${ }^{1}$ Leonard H Calabrese ${ }^{2}$
}

Hepatitis B virus (HBV) and tuberculosis have much in common. Approximately one-third of the world has been infected with each, and in the world of rheumatology, both represent important causes of infectious morbidity in patients who use biological and other immunosuppressive therapies. Furthermore, unlike most infections encountered in the biological setting, reactivation or progression of both hepatitis B and latent tuberculosis infection is largely preventable. Both infections can be screened for and preventive therapy is available and efficacious when employed correctly. Perhaps most pertinent to this editorial, the similarities do not end there. As for tuberculosis, there is variation in rheumatological practice and sometimes confusion, with optimal screening strategies often obscured by the fog of inadequate data and imperfect tests. The publication by Lan et $a l^{1}$ (pp. 1719) in this edition of Annals of Rheumatic Diseases helps clear the fog, adds important insights into the screening question, and provides strong data to suggest an optimal algorithm for HBV screening in this setting.

$\mathrm{HBV}$ is a DNA virus highly endemic in southeast Asia, Africa and other regions of the world outside of North America and western Europe, whereby most infection is transmitted perinatally (figure 1). ${ }^{2}$ If overlaid with the map for tuberculosis prevalence, one would be hard-pressed to distinguish the two. Within low prevalence regions, and also similar to tuberculosis, infection is more common among certain subgroups such as persons with HIV, a history of intravenous drug use, or a history of incarceration (box 1). In a substantial majority of HBV-infected patients, generally those

${ }^{1}$ Oregon Health and Science University, Portland, Oregon, USA

${ }^{2}$ Cleveland Clinic, Cleveland, Ohio, USA

Correspondence to Kevin L Winthrop, Oregon Health and Science University, Mailcode CEI, 3375 SW Terwilliger Boulevard, Portland, OR 97239, USA; winthrop@ohsu.edu infected perinatally, infection is chronic and life-long, frequently resulting in cirrhosis and eventually death. ${ }^{2}$ The lifetime risk of death among men from endemic regions with $\mathrm{HBV}$ approaches $40 \%$, with substantial risk among women noted although several fold lower. ${ }^{3}$ Worldwide, approximately one million persons die annually from hepatic complications from this virus. ${ }^{2}$ Among patients exposed to HBV, chronic infection (positive hepatitis B surface antigen; $\mathrm{HBsAg}$ ) is much more common in those coming from endemic areas where infection was acquired perinatally. ${ }^{4}$ In such cases, immune tolerance to infection occurs and the likelihood of chronic life-long infection is great. Conversely, in patients who develop infection later in life due to bloodborne or other exposure (primarily those cases from non-endemic regions), clearance of the virus and resolved infection is a much more common scenario. ${ }^{2}$ It is useful to understand this distinction when screening patients, as those coming from endemic areas will be much more likely to have chronic infection (ie, positive $\mathrm{HBsAg}$ ) or occult viraemia (negative HBsAg but quantifiable HBV-DNA titres from blood).

In general, the categorisation of HBVexposed patients is often confusing and can only be accomplished with the full battery of three serological tests for HBV (hepatitis B core antibody (HBcAb), Hepatitis B surface antigen ( $\mathrm{HBs} A g)$, and hepatitis B surface antibody (HBsAb)), with a fourth reserved to determining levels of infectiousness (hepatitis B e antigen). The meaning and utility of these tests is summarised in table 1 , and revisiting these definitions is essential in understanding a patient's risk of HBV progression during biological therapy. To begin, consider chronic HBV (defined by positive $\mathrm{HBs} \mathrm{Ag}$ ), in which the ability of $\mathrm{HBV}$ to progress under conditions of immunosuppression is well established. Within the rheumatological literature, numerous case reports and series exist documenting the potential for this complication during both anti-tumour necrosis factor (TNF) therapy and therapy with rituximab. ${ }^{5}$ For such patients, screening and management decisions are fairly clear. On the other extreme, patients who have no evidence of previous infection (ie, those with negative $\mathrm{HBcAb}$ ) are obviously not at risk of HBV progression, and an opportunity for HBV vaccination exists for unimmunised patients at risk of contracting HBV. Categorising patients that lie between these two extremes is more problematical, and deserves further consideration. For patients who have evidence of previous exposure ( $\mathrm{HBcAb}$ ), but who lack evidence of chronic active infection (HBsAg negative), the risks depend largely on whether the patient appears to have cleared their infection (ie, presence of $\mathrm{HBs} A b)$. When $\mathrm{HBcAb}$ is found in the presence of $\mathrm{HBs} A \mathrm{~b}$, this implies a degree (but not absolute) of protection and a state of healed infection; however, such patients, particularly when exposed to intense immunosuppression, can become HBsAg positive with progression of HBV. For those who lack HBsAb, the categorisation of 'resolved infection' is more tenuous. These individuals are more likely to demonstrate occult viraemia (positive HBV DNA) or have HBV DNA present within the liver, in which case they would be considered to have chronic infection.

So how do the data of Lan et $a l^{1}$ help clear the air? Their findings are in support of the categorisations above and of the known biology of HBV. They evaluated 106 consecutive RA patients before anti-TNF therapy and found remarkably that $90 \%$ of those patients had previous $\mathrm{HBV}$ exposure (positive $\mathrm{HBcAb}$ ), a number that seems exceedingly high even for a highly endemic region. Regardless of this, and most importantly, among the 12 HBsAg-negative/HBsAb-negative patients, they identified one-third of the patients to have occult viraemia. This finding underscores the reason why patient should not be screened with HBsAg alone before initiating anti-TNF therapy. Second, among the 58 patients with HBsAg-negative/HBsAb-positive status (ie, seemingly resolved HBV), none of the 58 experienced HBV reactivation during subsequent anti-TNF therapy. ${ }^{6}$ A number of other published case series also attest to a lack of risk in anti-TNFtreated patients with healed (HBsAgnegative/HBsAb-positive status) $\mathrm{HBV}$ infection. ${ }^{7}$ While these findings are reassuring, however, there is at least one case of $\mathrm{HBV}$ progression reported in a $\mathrm{HBs} \mathrm{Ag}$ - 


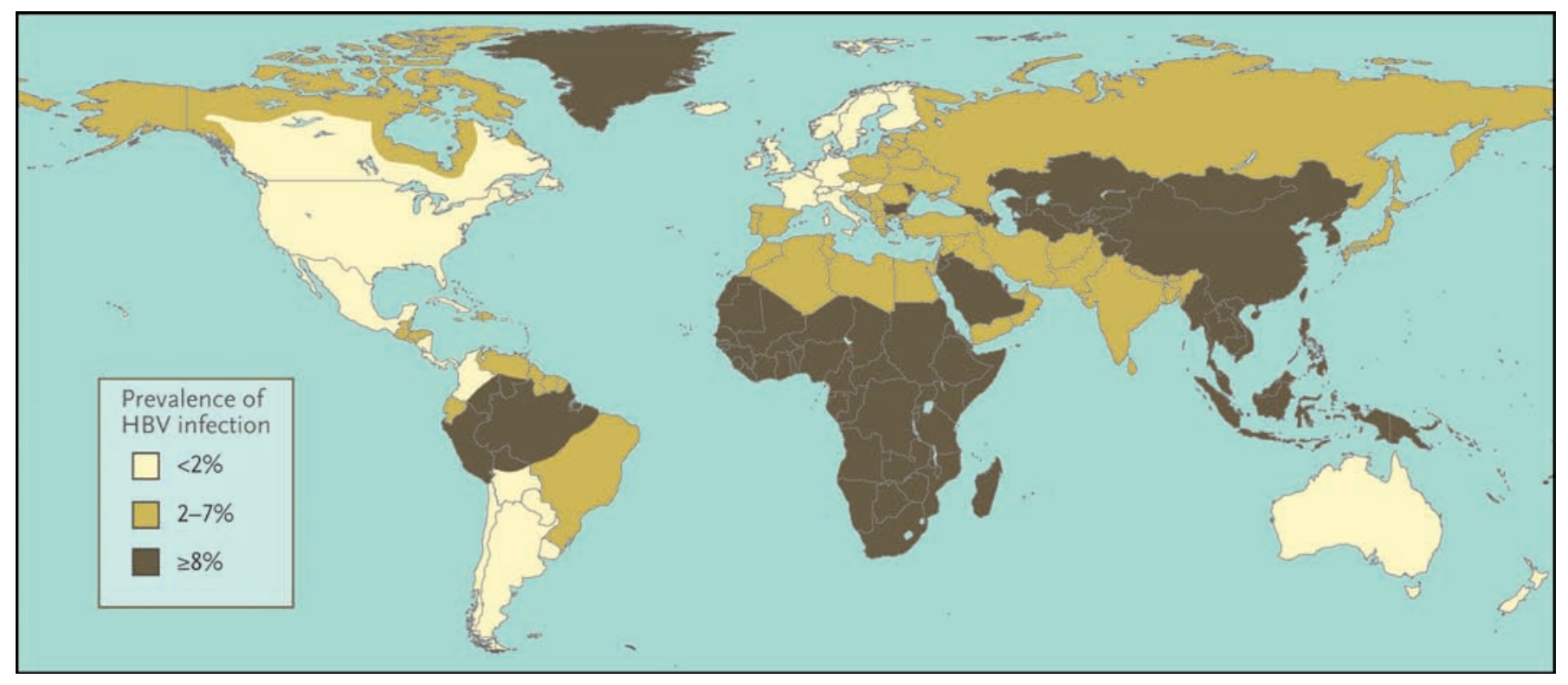

Figure 1 World map of hepatitis B virus (HBV) prevalence. ${ }^{2}$

negative/HBsAb-positive patient using anti-TNF therapy, ${ }^{8}$ and it is apparent from other immunosuppressive conditions that such patients can undergo 'seroreversion' in which they regain $\mathrm{HBs} A g$ positivity (and lose $\mathrm{HBs} \mathrm{Ab}$ positivity). Lan et al ${ }^{1}$ and others have noted that patients' $\mathrm{HBs} \mathrm{Ab}$ levels can decline during anti-TNF therapy, further raising the possibility that prolonged therapy in some individuals could promote seroreversion and HBV progression. $^{1} 910$ Accordingly, patients meeting this profile should be screened periodically during anti-TNF therapy for potential HBV recrudescence.

So how do rheumatologists screen for HBV? In 2008, the American College of Rheumatology published guidelines for the use of biological therapy in which no detailed screening algorithm was recommended. ${ }^{11}$ The document did, however, warn readers of the potential for $\mathrm{HBV}$ reactivation during anti-TNF therapy, but it did not provide guidance regarding how to screen. A recent survey conducted among American rheumatologists suggested that nearly $50 \%$ of rheumatologists relied upon $\mathrm{HBs} \mathrm{Ag}$ only to screen patients. ${ }^{11}$ The data from Lan et al highlight the danger in such a screening algorithm, in that a substantial proportion of patients with previouis HBV exposure who lack HBsAg might in fact have occult chronic HBV (this would be particularly more likely in those coming from endemic regions).

The bottom line? The data accumulated to date, and the known biology of $\mathrm{HBV}$, imply that screening patients before

\section{Box 1 Risk factors for HBV and recommended groups for screening}

Patients who should be screened for HBV infection in rheumatology practice

1. All patients commencing immunosuppressive and or immunomodulatory therapy*

2. All patients with high-risk behaviour including:

- High-risk sexual activity including those with sexually transmitted diseases, multiple sexual partners and men who have sex with men

- Intimate contacts of HBV-infected individuals

- Injectable drug users

3. All individuals from endemic areas with prevalence of $\mathrm{HBV}$ greater than $2 \%$ and their unimmunised offspring ${ }^{\dagger}$

*Including antimetabolites, alkyators, high-dose glucocorticoids and biological therapies.

${ }^{\dagger}$ Mediterranean basin, eastern Europe, Middle East, Asia, Africa, central and South America,

Pacific Islands, Alaska (MMWR 57(RRo8);1-20.)

biological therapy should utilise all three serological markers of HBV exposure and immunity including $\mathrm{HBcAb}, \mathrm{HBsAg}$ and $\mathrm{HBs} \mathrm{Ab}$, and baseline serum HBV-DNA assessment to rule out occult viraemia in any patient with $\mathrm{HBcAb}$ positivity (particularly in those lacking HBsAb). Based on these results, we suggest categorising patients into four groups: no history of HBV; vaccinated for $\mathrm{HBV}$; resolved $\mathrm{HBV}$ and chronic $\mathrm{HBV}$ (table 2). For patients classified as having chronic infection (ie, HBsAg positivity), therapy with biological agents are not necessarily contraindicated. As in the study by Lan et al, ${ }^{1}$ a number of published accounts suggest that the concurrent use of appropriate antiviral therapy can keep HBV levels and hepatic enzymes stable during therapy, ${ }^{12}$ although the long-term safety of such concurrent therapy has not yet been documented. For those patients caught in the middle with 'resolved HBV' (ie, $\mathrm{HBcAb}$ positive either alone or in combination with $\mathrm{HBs} A b$ ), patients should be monitored for HBV progression during biological therapy (table 2). Finally, for those without previous HBV exposure or vaccination, HBV vaccine should be considered in those persons at risk of HBV acquisition according to local or regional guidelines.

So like tuberculosis, complications with HBV are generally preventable and manageable in this setting, but it is a problem that will not soon go away. As biological therapies expand into regions of the globe where these chronic infections are highly prevalent, and as patients from endemic regions continue to travel and immigrate to regions of low prevalence, pursuing appropriate screening algorithms for HBV will only continue to gain importance. 
Table 1 Interpretation of hepatitis B serological and screening tests

Hepatitis B lab nomenclature

$\mathrm{HbsAg} \quad H$ Hepatitis B surface antigen is a marker of infectivity in acute or chronic HBV infection.

$\mathrm{HbsAb} \quad$ Antibody to surface antigen is a marker of immunity and most often found in isolation in HBV immunised patients. It is also found in conjunction with $\mathrm{HBCAb}$ in resolved infection and rarely in isolation in naturally infected individuals.

$\mathrm{HbcAb} \quad$ Antibody to core antigen is a marker of acute (lgM), chronic (lgG) or resolved HBV infection. In the absence of $\mathrm{HBsAg}, \mathrm{HBcAb}$ is generally found in conjunction with $\mathrm{HBsAb}$ and is a marker of resolved infection. In isolation it may represent a false positive test or indicate 'occult' HBV infection.

HbeAg HB e antigen is a marker of a high degree of HBV infectivity, correlating with a high level of HBV replication. $\mathrm{HB}$ e antigen is absent in patients with core and pre-core mutants.

$\mathrm{HbeAb} \quad$ Antibody to hepatitis $\mathrm{B}$ e antigen may be present in infected or immune individuals. In persons with chronic HBV, the presence of HBeAb suggests a low level of infectivity.

HBV DNA HBV DNA is a direct marker of HBV replication and correlates with disease activity. In blood it is used to monitor treatment. HBV may be detected in the absence of HBsAg with or without anti$\mathrm{HBc}$ and when present represents active $\mathrm{HBV}$ infection

$H B V$, hepatitis $B$ virus; IgG, immunoglobulin G; IgM, immunoglobulin M.

Table 2 Proposed functional HBV categorisation of patients based on screening test results

\begin{tabular}{|c|c|c|c|}
\hline & Screening test results & $\begin{array}{l}\text { Risk of progression during } \\
\text { biological therapy }\end{array}$ & Management considerations \\
\hline Never infected & $\begin{array}{l}\text { HBcAb negative, } \\
\text { HBsAg negative, } \\
\text { HBsAb negative }\end{array}$ & None & $\begin{array}{l}\text { Consider HBV } \\
\text { vaccination if at risk of } \\
\text { acquiring HBV }\end{array}$ \\
\hline HBV vaccinated & $\begin{array}{l}\mathrm{HBcAb} \text { negative, } \mathrm{HBsAg} \\
\text { negative, HBsAb positive }\end{array}$ & None & N/A \\
\hline \multirow[t]{2}{*}{ Resolved HBV* } & $\begin{array}{l}\text { HBcAb positive, } \mathrm{HBsAg} \\
\text { negative, HBsAb positive }\end{array}$ & $\begin{array}{l}{ }^{\dagger} \text { Immunity suggested } \\
\text { Low risk (but not zero) }\end{array}$ & $\begin{array}{l}\text { Obtain baseline HBV DNA } \\
\text { If positive: patient has } \\
\text { chronic HBV }\end{array}$ \\
\hline & $\begin{array}{l}\mathrm{HBcAb} \text { positive, } \mathrm{HBsAg} \\
\text { negative, HBsAb negative }\end{array}$ & $\begin{array}{l}{ }^{\ddagger} \text { Immunity not clear } \\
\text { Low to moderate risk of } \\
\text { progression }\end{array}$ & $\begin{array}{l}\text { If negative: periodic } \\
\text { monitoring of HBV-DNA } \\
\text { levels and liver function } \\
\text { tests during biological } \\
\text { therapy }\end{array}$ \\
\hline \multirow[t]{2}{*}{ Chronic HBV } & $\begin{array}{l}\text { HBsAg positive, } \\
\text { (regardless of other } \\
\text { results) }\end{array}$ & High & $\begin{array}{l}\text { If biological therapy is not } \\
\text { avoidable, then refer to GI or } \\
\text { ID specialist for concurrent } \\
\text { and appropriate anti-HBV } \\
\text { therapy }\end{array}$ \\
\hline & & & $\begin{array}{l}\text { Periodic monitoring of } \\
\text { HBV-DNA levels and liver } \\
\text { function tests during } \\
\text { biological therapy }\end{array}$ \\
\hline
\end{tabular}

\footnotetext{
* Patients in this category may also rarely be HBsAb positive in isolation.
}

'Patients with $\mathrm{HBsAb}$ positivity have probably cleared their virus, although there still exists a small risk of seroreversion and reactivation during immunosuppresssion. ${ }^{8}$

${ }^{\ddagger}$ In the case of HBsAb negativity, this substantially increases the risk that a patient has not cleared their HBV infection. Some proportion of these patients have either occult viraemia (detectable serum HBV DNA) or can reactivate later during immunosuppression in which HBV DNA and/or surface antigen will become detectable. $H B c A b$, hepatitis $B$ core antibody; $H B s A b$, hepatitis $B$ surface antibody; $H B s A g$, hepatitis B surface antigen; $\mathrm{HBV}$, hepatitis $B$ virus.

\section{Competing interests None.}

Provenance and peer review Commissioned; externally peer reviewed.

Accepted 8 June 2011

Ann Rheum Dis 2011;70:1701-1703

doi:10.1136/annrheumdis-2011-200163

\section{REFERENCES}

1. Lan J, Chen Y, Hsieh TC, et al. Kinetics of viral loads and risk of $\mathrm{HBV}$ reactivation in $\mathrm{HBCAb}$ positive RA patients undergoing anti-TNF- $\alpha$ therapy. Ann Rheum Dis 2011;70:1719-25.

2. Dienstag JL. Hepatitis $B$ virus infection. N Engl J Med 2008;359:1486-500

3. Beasley RP, Hwang LY, Lin CC, et al. Hepatocellular carcinoma and hepatitis B virus. A prospective study of 22707 men in Taiwan. Lancet 1981;2:1129-33.

4. Ganem D, Prince AM. Hepatitis B virus infectionnatural history and clinical consequences. N Engl J Med 2004;350:1118-29.

5. Calabrese LH, Zein NN, Vassilopoulos D. Hepatitis B virus $(\mathrm{HBV})$ reactivation with immunosuppressive therapy in rheumatic diseases: assessment and preventive strategies. Ann Rheum Dis 2006;65:983-9.

6. Lin CC, Hsieh HS, Huang YJ, et al. Hepatitis B virus infection among pregnant women in Taiwan: comparison between women born in Taiwan and other southeast countries. BMC Public Health 2008;8:49.

7. Caporali R, Bobbio-Pallavicini F, Atzeni F, et al. Safety of tumor necrosis factor alpha blockers in hepatitis $B$ virus occult carriers (hepatitis $B$ surface antigen negative/anti-hepatitis B core antigen positive) with rheumatic diseases. Arthritis Care Res (Hoboken) 2010;62:749-54.

8. Montiel PM, Solis JA, Chirinos JA, et al. Hepatitis B virus reactivation during therapy with etanercept in an HBsAg-negative and anti-HBs-positive patient. Liver Int 2008;28:718-20.

9. Vassilopoulos D, Apostolopoulou A, Hadziyannis E, et al. Long-term safety of anti-TNF treatment in patients with rheumatic diseases and chronic or resolved hepatitis B virus infection. Ann Rheum Dis 2010:69:1352-5.

10. Lubel JS, Angus PW. Hepatitis B reactivation in patients receiving cytotoxic chemotherapy: diagnosis and management. J Gastroenterol Hepatol 2010:25:864-71.

11. Stine JG, Khokhar OS, Charalambopoulos J, et al. Rheumatologists' awareness of and screening practices for hepatitis B virus infection prior to initiating immunomodulatory therapy. Arthritis Care Res (Hoboken) 2010;62:704-11.

12. Carroll MB, Forgione MA. Use of tumor necrosis factor alpha inhibitors in hepatitis B surface antigen-positive patients: a literature review and potential mechanisms of action. Clin Rheumatol 2010;29:1021-9. 